\title{
ANCILLARY REVENUE PRICING
}

Andreas Wittmer ${ }^{9}$

Head Center for Aviation Competence, University of St Gallen, Dufourstrasse, Switzerland Nicole Oberlin ${ }^{10}$

Univerisity of Applied Science, Zurich, Switzerland

\section{ABSTRACT}

The airline industry has evolved from a system of long-established state owned carriers operating in a regular market to a dynamic, deregulated industry. This development - especially the emerging competition of low-cost carriers - has had a major influence on the price setting behaviour of airlines. Profitability of airlines is limited and pricing systems are reconsidered.

To stay competitive, traditional full service carriers consider the implementation of ancillary revenue systems, which are similar to low-cost carriers. This paper investigates challenges of an ancillary revenue pricing approach for full service network carriers.

A qualitative means-end approach is used to find attributes, which are important for air passengers, and influence their ticket buying behaviour. In addition, the study provides insight into the perception of an ancillary revenue system in the full service network carrier market.

The findings present 18 ticket purchase attributes and 15 behavioural terminal values in hierarchical value maps. Based on these values, it is evident that most passengers appreciate if some services are included in the price and not offered as ancillaries. Benefits of ancillary revenue systems include the individual ticket creation, customisation, improved price-performance ratio, flexibility gains and progressive ideas. The main drawbacks of the system include a complicated and complex booking process, feelings of uncertainty, branding problems, a distortion of competitive behaviours, a system similar to that of low-cost carriers, feelings of paying extra for every service and a perceived decline in service and quality.

Keywords: Airlines, ancillary revenues, full service network carriers, pricing strategies

9 Andreas Wittmer, Dr., Head Center for Aviation Competence, University of St. Gallen, Dufourstrasse 40a, CH-9000 St. Gallen, Switzerland, phone +41 (0)71 22425 25, andreas.wittmer@unisg.ch

10 Nicole Oberlin, BSc, University of Applied Sciences Chur, Hardstrasse 63, CH-8004 Zurich, Switzerland, phone +41(0)79 30441 17, nicole.oberlin@tbwil.ch 


\section{INTRODUCTION}

The airline industry has evolved from a system of long-established state owned carriers operating in a regular market to a dynamic, deregulated industry. This development - especially the emerging competition of low-cost carriers (LCCs) - has had a major influence on the price setting behaviour of airlines. Profitability of airlines is limited and pricing systems are reconsidered.

One newly emerged strategy, which finds its origins in lowcost carrier business models, is the ancillary revenue system. This system began with the increase in oil prices in 2002 when airlines imposed additional fees for upgrades to the ticket fare. Soon thereafter, this change extended into fees for other services such as meals, baggage and seating assignments, thereby considerably increasing the expected revenues.

However, there are certain risks connected to this pricing strategy as it is a typical characteristic of LLC's. Hence, the implementation of such a system might damage the image of full service carriers representing traditional values, high quality product and quality services as well as customer orientation by offering individual support. Therefore, it must be proven whether such a pricing approach fits within the overall marketing strategy and within the holistic corporate image.

The goal of this study is to determine and answer the following research questions:

- Could an ancillary revenue pricing approach be a suitable and successful pricing strategy for full service carriers?

- Is there a willingness and acceptance to pay for auxiliary services?

- Which attributes and attribute levels have a major influence on the ticket purchase-decision process both during the flight experience as well as on post-purchase behaviour?

- How can ancillary revenue components be bundled to maximise customer utility?

- What impact might an ancillary revenue approach have on the image of a full service network carrier? 


\section{THEORETICAL FRAMEWORK}

\subsection{Pricing Strategies in the Airline Industry}

In today's world, air transportation services are affordable to the majority of society. However, upon closer examination of the development of the airline industry, it is evident that this has not always been the case. One major factor that has contributed to the current situation is the airline deregulation phase of 1978 (Peoples, 2012).

The emergence of low-cost carrier business models combined with the development of the Internet as a major marketing tool are especially challenging for full service network carriers. To cover high fixed costs full service airlines must reconsider and rebuild their pricing strategies. It is often impossible to establish reasonable airfares that cover all costs. To address the high fixed costs, some full service network carriers either adopt the LCC business models or establish low-cost carrier subsidiaries that are inserted into distinct low-cost carrier routes or markets (Basso et al., 2008).

Carrier pricing strategies are often complicated and incomprehensible because a variety of internal and external factors influence the cost structure. Nevertheless, the numerous strategies can be categorised into overall strategies, which is essential for understanding pricing behaviour (Chi et al., 2009). Overall, the pricing strategies can be classified as linear or nonlinear. In the airline industry, linear pricing is used in connection with the concept of flat rates whereas nonlinear pricing reflects other strategies. These nonlinear strategies are commonly used in highly competitive, incomplete market environments with imperfect information. In contrast to linear pricing, nonlinear strategies reflect the concept that customers pay different ticket fares without justification for identical or similar flights (Hernandez et al., 2012).

Airline pricing strategies can be broadly classified as traditional pricing, LCC pricing, dynamic pricing and newly emerged pricing strategies.

\section{TRADITIONAL AIRLINE PRICING}

In traditional airline pricing, the revenue management uses several price levels and inventory systems. Air fares are established and adapted based on capacity, market conditions and demand forecasts. In contrast to other strategies, competitive prices are not explicitly examined as it is assumed that they already influence general market conditions.

Because price transparency has increased in importance during the last 20 years, customers now compare airfares from different providers. Accordingly, it has become imperative that airlines constantly predict and assess current as well as future market conditions. Moreover, they must adapt their prices immediately. Global distribution systems and travel agents enable airlines to 
obtain information about specific needs of consumers, such as ideal departure times and preferred airlines. Additionally, these global systems allow for the modification of prices based on general business policies (Gunther et al., 2012).

\section{DYNAMIC PRICING}

Although, dynamic pricing was originally perceived as a low-cost carrier pricing strategy, today it is often adapted by legacy carriers and appears in various forms. Yield management can be understood as dynamic pricing as both terms represent a method of maximizing returns by defining dynamic prices that differ according to seat load factors and booking or consumption times. Moreover, differentiations can occur due to specific market segments.

Ancillary revenues play an important role in dynamic pricing and can be subdivided into three main strategies, namely, unbundling, traditional fares with add-ons and bundling (Wittmer et al. 2012, Wittmer, Rowley, 2014).

Unbundling is also referred to as the offering of à la carte services. A la carte simply means that customers can choose services from the menu. It is a pricing mechanism that displays the description and prices of individual product and service attributes offered with a flight ticket (Granados et al., 2012). A pure a la carte pricing approach is primarily provided by low-cost carriers. In addition to the basic flight, customers pay separately for almost every additional service such as checked bag, reserved seating, etc. (Tuttle, 2012).

The objective of unbundled pricing is to fight back against commoditisation and sustain the position of direct distribution channels. Furthermore, customers prefer flexibility in choosing services that maximise utility based on their requirements. Because GDS and online travel agencies enabled consumers to easily compare air fares, airline revenues continuously decreased, and as a result, many airlines started the à la carte pricing in their direct distribution system to inform customers about the various product bundles and (Luo et al., 2007; Granados et al., 2012).

Another type of dynamic pricing are fare options, which enable travellers to choose between different service packages according to their requirements (Tuttle, 2012).

Air Canada and Air New Zealand were among the first airlines to introduce a strategy with fare options. On the one hand, they maintained the traditional product, which includes the flight, hand luggage as well as on-board catering, while on the other hand, they began providing a defined set of add-on services (Air Canada, 2013). 
The third ancillary revenue strategy is called bundling and refers to the situation where an airline provides several predefined packages for different customer groups with the option of adding specific services. This strategy, which is quite new, is essentially a further extension of fare options.

\section{NEWLY EMERGED PRICING APPROACHES}

In more recent times, some airlines have attempted to adapt their pricing strategies by implementing new forms. One such approach is the pay-by-weight pricing system, also known as pay-by-the-pound, a rather simple approach first introduced by Samoa Air. While booking a flight ticket, passengers are requested to indicate their approximate body weight as well as the expected weight of their luggage in kilograms. Based on that data, the system then calculates the overall airfare for the passenger (Samoa Air, 2013).

Another approach is the variable pricing system, which was introduced by Allegiant Air in 2011. This pricing system is based on the agreement that customers pay a final ticket price depending on the cost of fuel cost at the time of take-off. Thus, travellers pay a certain ticket price at the time of the reservation but may be assessed an additional fee if fuel prices have increased by the time of departure (Tuttle, 2013a).

There is also the personalised or customised pricing system model. To date, however, this model has only been discussed at the theoretical level; it has not been implemented. According to this approach, passengers pay a flight price based on their individual travel and purpose history. Furthermore, other aspects, such as nationality or marital status of the passenger, would influence the airfare composition. Accordingly, the airfare is not influenced by time of purchase or choice of seat class but rather by personal factors (Tuttle, 2013b).

\subsection{Consumer Decision Making}

How people behave when facing the challenge of making decisions is a widely discussed subject in common literature. The theory of judgment and decision making can be found in the disciplines psychology, sociology, business management, economics, political sciences, medical sciences, engineering and other fields (Arkes \& Hammond, 1988). In the current study, the theory of judgment is used in the field of business management to explain the behaviour of consumers. More specifically, how consumers evaluate offerings and make buying decisions.

Judgment is "the mental or intellectual process of forming an opinion or evaluation by discerning and comparing" (Merriam-Webster, 2014). In other words, it is the power or ability to make a decision based on the evidence (Arkes \& Hammond, 1988). 
Although there are studies about judgment and decision making that date back to 1918 (Thorndike, 1918; Edwards, 1954; Hammond, 1955), the systematic empirical study of judgment and decision making began in the 1960s. This was especially the case in the field of cognitive psychology, which focused on motivational research. Decision analysis focuses on a priori decomposition, which is the separating of the decision process into several components before making the decision (Arkes \& Hammond, 1988). According to this theory, consumers must fulfil a multifaceted task when making buying decisions as they are often faced with several alternatives and a large number of product attributes that must first be evaluated (Solomon, 2013, Wittmer, Riegler, 2013). Consumer decisionmaking models explain the problem solving process, a process that begins with the recognition of a need. Consequently, to solve the problem, the customer must pass through several steps including a search for information search, the evaluation of alternatives and the process of purchase and post-purchase evaluations (Howard \& Sheth, 1969; Engel et al., 1973). Because the consumer has well-defined preferences and aims to maximise utility, the he or she chooses the option that maximises his or her received value (Bettman et al., 1998). Consumers, when confronted with difficult value trade-offs, such as price versus convenience (Bettman et al., 1991), apply either a heuristic or a systematic decision process (Gigerenzer \& Gaissmaier, 2011; Doyle, 1998).

As the individual's brain is not able to process all of the available information, it applies specific decision rules to evaluate product alternatives. Reisen et al. (2008) found that in the early stages of the decision-making process, individuals tend to use heuristic decision-making strategies. In later stages and until the end of the process, the individual evaluates the alternatives more carefully. During this phase, consumers trade off price against other factors and then make their purchase decision. Hence, it could be assumed that price is the instrumental factor that dominates systematic decisions, whereas other product attributes are prevailing factors when making heuristic choices.

During this decision-making process, consumers are influenced by a variety of factors, including those of a situational, sociocultural or psychological nature, as well as by the marketing mix of the different suppliers. While developing the marketing strategy and mix, companies should be aware of this process and its influencing factors to take advantage of them (Solomon, 2011).

The means-end theory, developed by Gutman in the early 1990s, is a concept based on customer behaviour knowledge. The model makes it possible to connect peoples' behaviours with consumer values in what are known as means-end chains. Means are understood as products, objects or activities whereas ends reflect desired states of being (Gutman, 1981). The goal of this theory is not only to identify explicit consumer relations and build attitudes towards products but also to discover and analyse the implicit nature of this correlations between product attributes and personally developed values. Figure 12 illustrates this process in a simplified way (Kuss et al., 2007a). 
Figure 1: Means-end process

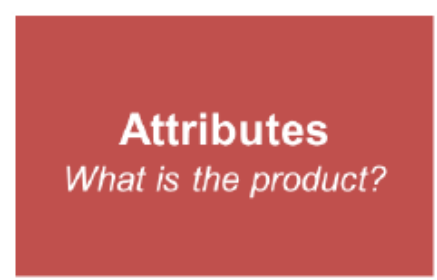

Consequences

What does the product

deliver to the

consumer?

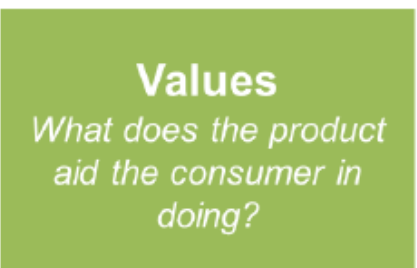

Concrete attributes

What are the tangible aspects of the product?

Abstract attributes

What are the intangible aspects of the product?

Functional Consequence

What does the product actually do?

Psychological Consequence

What does the consumer think the product does? What does he think others will think of the product?

\section{Instrumental Values}

What short term goals, if any, does the product help to achieve?

\section{Terminal Values}

What long term or life goals, if any, does the product help to achieve?

Source: Kuss et al., 2007a

Figure 1 illustrates the holistic means-end process in greater detail. The product attributes such as the price or the quality are identified first. The attribute level is then subdivided into tangible attributes and intangible attributes. Attributes are linked with consequences, which are divided into functional and psychological (UXmatters, 2013). Functional consequences reflect the tangible or physical-tangible outcomes of using a certain product, such as eating a meal that satisfies hunger or using a car to travel from one location to another. Psychological consequences represent the psychological as well as the social outcomes of product usage. Usually, these consequences are internally or personally perceived, reflecting how the consumption of a product affects one's emotional state. For instance, the use of a certain shampoo might cause the consumer to feel more attractive or the wearing of a certain brand may cause one to feel more stylish. These affective qualities are often linked with expected social consequences, for example, how your friends perceive you. Consumers might experience both positive and negative consequences. Given that customers usually focus on the accumulated benefits they receive by consuming a product than about product attributes in general, the segmentation of consumer groups should rely heavily on this knowledge.

However, consumers also consider the undesirable consequences of using a product. These consequences are the perceived risks associated with the purchase of a product and can be divided into physical, financial, functional and psychosocial risks. During the purchase decision process, consumers are constantly weighing the perceived benefits and risks of a product or service with the 
intent to make the best possible decision. As such, core values are at the bottom of the hierarchy and are split into instrumental and terminal values. In general, because these values are derived from people's life goals, they incorporate certain emotional associations with those goals. Instrumental values, for example, reflect preferred modes of behaviour such as acting as an independent person, demonstrating responsibility and thinking logically. Terminal values, on the other hand, are favourable states of being or broad psychological states such as being happy, feeling attractive, being considerate or receiving social recognition (Wittmer, Riegler, 2013, McGrawHill, 2013).

\section{RESEARCH PROCEDURE AND DATA}

As the aim of this paper is to investigate and analyse whether an ancillary revenue pricing system can be a successful strategy for full service network carriers, theoretical and empirical research was conducted. The theoretical portion of the study focused on the various pricing strategies and consumer behaviour whereas the empirical data were obtained from qualitative interviews. The interviews focused on five ancillary revenue options, namely, the basic flight, seat reservations, free checked bags, rebooking/cancellation options and business class upgrades. The goal of the qualitative interviews was to investigate four different areas, all of which influence or are linked with the implementation of an ancillary revenue system.

First, the results of the interviews provided valuable clues regarding attributes and attribute levels that influence customer purchase behaviour, customer experience and customer post-evaluation of a flight offer. These attributes have been used to identify the underlying consumer preferences, and as such, they serve as simulators of purchase behaviour.

Second, this study investigated what passengers expect from the various airline categories, such as low-cost carriers, major network airlines that include carriers such as Lufthansa and British Airways and premium airlines such as Singapore Airlines and Emirates. The objective was to gain insight about the general perception of different airline categories and to gain an understanding of the main distinctive attributes. Furthermore, the possible impact of an ancillary revenue pricing system on the future image perception of full service network carriers was explored.

The survey was highly linked to consumer behaviour. The means-end theory of Gutman (1981) provides an approach to measure behaviour based on final values. The laddering method, which is derived from the means-end theory, was specifically used while developing the interview guide and during the final analysis. Laddering provides insight into the demand side, thus enabling marketers to explain the meaning of product attributes to consumers and to present their underlying consequences and values. Accordingly, these insights into consumer behaviour can be effectively 
used in future marketing activities.

The data for the analysis were collected through semi-structured, one-to-one, in-depth interviews that were administered to a sample of 18 persons. On average, an interview with the selected persons, according to the quota sampling plan, ranged from 30 to 45 minutes.

\section{$4 \quad$ ANALYSIS AND RESULTS}

\subsection{Ticket Purchase Decision Attributes}

During the interview, the participants were asked during the flight experience and after the purchase to identify the attributes they considered important when purchasing their tickets. Moreover, additional attributes were also investigated during the survey. The aim of this approach was to identify different attributes and their levels of importance and to analyse the underlying associated instrumental and terminal values using hierarchical value maps.

\section{ATTRIBUTES \& ATTRIBUTE LEVELS}

A comparison of the responses of the 18 interviewees indicated that while the majority value similar attributes, there are some discrepancies with respect to attribute levels. Table 1 presents the attributes and the attribute levels most frequently mentioned by the participants. 
Table 1: Attribute levels and explanations

\begin{tabular}{|c|c|c|}
\hline Attribute & Attribute level & Description \\
\hline Service Quality & $\begin{array}{l}\text { Quality of service } \\
\text { friendly staff } \\
\text { cooperative, helpful } \\
\text { staff professional staff } \\
\text { customer care } \\
\text { customer support }\end{array}$ & $\begin{array}{l}\text { Service quality was mentioned with respect to } \\
\text { the general degree of good or bad service on } \\
\text { the plane; the friendliness, cooperativeness } \\
\text { and professionalism of the staff; the customer } \\
\text { support at the airport or via hotlines; and the } \\
\text { perceived individual customer care. }\end{array}$ \\
\hline Cost Element & $\begin{array}{l}\text { Ticket price } \\
\text { cost-performance ratio } \\
\text { additional/hidden costs }\end{array}$ & $\begin{array}{l}\text { The cost attribute of a flight ticket was } \\
\text { mentioned in connection with overpriced or } \\
\text { cheap tickets, bargain offers, additional and } \\
\text { hidden costs, cost-performance relationship } \\
\text { and general cost savings. }\end{array}$ \\
\hline Food \& Beverage & $\begin{array}{l}\text { On-board catering } \\
\text { quality of food/ } \\
\text { beverages } \\
\text { variety of choice }\end{array}$ & $\begin{array}{l}\text { This attribute was addressed in connection } \\
\text { with on-board catering, either free or at a cost } \\
\text { and referenced. the quality of the food } \& \\
\text { beverage and the variety of options. }\end{array}$ \\
\hline Time Element & $\begin{array}{l}\text { Direct flight } \\
\text { flight schedule } \\
\text { transfers/stopovers } \\
\text { punctuality } \\
\text { handling/transaction } \\
\text { time delays strikes }\end{array}$ & $\begin{array}{l}\text { This element was mentioned in connection } \\
\text { with time savings, which occur at the attribute } \\
\text { levels; flight schedules (time of departure \& } \\
\text { arrival); direct flights; transfers/stopovers; } \\
\text { efficient handling or transaction times; } \\
\text { punctuality; delays and strikes }\end{array}$ \\
\hline $\begin{array}{l}\text { Holistic Quality } \\
\text { On All Levels }\end{array}$ & $\begin{array}{l}\text { Plane condition } \\
\text { staff education/service } \\
\text { food \& beverage quality } \\
\text { comfort level of } \\
\text { equipment }\end{array}$ & $\begin{array}{l}\text { This element reflects the perceived quality on } \\
\text { all levels on-board and on the ground. It was } \\
\text { referenced with respect to the maintenance } \\
\text { and the overall condition of the plane and } \\
\text { maintenance, the level of education of the } \\
\text { staff, the quality of the food and beverage and } \\
\text { the comfort level of the equipment. }\end{array}$ \\
\hline
\end{tabular}




\begin{tabular}{|c|c|c|}
\hline Flight Comfort & $\begin{array}{l}\text { Comfortable flight } \\
\text { comfortable seats } \\
\text { legroom/space } \\
\text { convenience products } \\
\text { air quality climate } \\
\text { cleanliness }\end{array}$ & $\begin{array}{l}\text { This attribute addresses comfort level with } \\
\text { respect to the seats, the general space } \\
\text { between seats and other equipment and } \\
\text { legroom. Also mentioned was air quality, } \\
\text { general climate plane the plane, cleanliness } \\
\text { and convenience products such as } \\
\text { headphones, blankets, pillows, magazines, etc. }\end{array}$ \\
\hline $\begin{array}{l}\text { Condition Of } \\
\text { Fleet/ Planes }\end{array}$ & $\begin{array}{l}\text { Age of plane } \\
\text { equipment } \\
\text { maintenance } \\
\text { design } \\
\text { technology }\end{array}$ & $\begin{array}{l}\text { The condition of the plane was mentioned in } \\
\text { connection with the age of the fleet (modern } \\
\text { or outdated and the general impression of the } \\
\text { equipment and maintenance of the plane, the } \\
\text { overall exterior and interior design of the plane } \\
\text { and the relevant technology of the plane. }\end{array}$ \\
\hline $\begin{array}{l}\text { Security \& Safety } \\
\text { Standards }\end{array}$ & $\begin{array}{l}\text { Airline brand } \\
\text { familiarity with } \\
\text { processes } \\
\text { condition of plane } \\
\text { staff training } \\
\text { safety instructions }\end{array}$ & $\begin{array}{l}\text { The security and safety attribute was } \\
\text { mentioned in connection with the condition of } \\
\text { the planes, the brand of an airline, the } \\
\text { professionalism of the staff, the familiarity with } \\
\text { the processes and the communicated safety } \\
\text { instructions. }\end{array}$ \\
\hline Airline Choice & $\begin{array}{l}\text { Brand image } \\
\text { reliability } \\
\text { confidence } \\
\text { familiarity } \\
\text { past experiences }\end{array}$ & $\begin{array}{l}\text { With respect to the airline they fly, most } \\
\text { interviewees emphasised the importance of } \\
\text { brand image and the degree of confidence } \\
\text { they have in the brand, the reliability of the } \\
\text { brand and their familiarity with the processes } \\
\text { according to past experiences. }\end{array}$ \\
\hline Choice Of Offers & $\begin{array}{l}\text { Additional services class } \\
\text { (economy, business, } \\
\text { first) destination choice }\end{array}$ & $\begin{array}{l}\text { This attribute reflects the perceived choice of } \\
\text { offers such as additional services, flight class } \\
\text { and the variety of offered destinations. }\end{array}$ \\
\hline $\begin{array}{l}\text { Entertainment } \\
\text { System }\end{array}$ & $\begin{array}{l}\text { Technology/state-of-the } \\
\text { art contemporary } \\
\text { choice of films/games, } \\
\text { etc. } \\
\text { multilingual options }\end{array}$ & $\begin{array}{l}\text { The entertainment system was mentioned with } \\
\text { respect to the quality of the technology, the } \\
\text { contemporariness of the technology, movies, } \\
\text { etc. the choices offered with respect to } \\
\text { movies, games, etc. and the multilingual } \\
\text { options offered }\end{array}$ \\
\hline
\end{tabular}




\begin{tabular}{|c|c|c|}
\hline Flexibility & $\begin{array}{l}\text { Individual ticket choice } \\
\text { choice of flights } \\
\text { rebooking option } \\
\text { cancellation option } \\
\text { upgrade option }\end{array}$ & $\begin{array}{l}\text { The element flexibility was mentioned in the } \\
\text { context of individual ticket choice, the choice } \\
\text { of flights, the rebooking or cancellation option } \\
\text { and the upgrade option. }\end{array}$ \\
\hline Feel Of "Flying" & $\begin{array}{l}\text { Flight as an experience } \\
\text { design of servicescape }\end{array}$ & $\begin{array}{l}\text { Participants stated that using a plane should } \\
\text { transmit a special feeling of flying and } \\
\text { therefore the servicescape, such as interior } \\
\text { design, clothing of the staff, the processes and } \\
\text { the overall contact should be designed in a } \\
\text { unique way to evoke that special experience. }\end{array}$ \\
\hline Stress-Free Travel & $\begin{array}{l}\text { Well-organised } \\
\text { (package) } \\
\text { reliability, punctuality } \\
\text { confidence, familiarity }\end{array}$ & $\begin{array}{l}\text { The flight and the processes associated with } \\
\text { the flying experience should be as organised } \\
\text { and as stress-free as possible. }\end{array}$ \\
\hline $\begin{array}{l}\text { Customer } \\
\text { Involvement }\end{array}$ & $\begin{array}{l}\text { Purchasing of ticket } \\
\text { e-ticket } \\
\text { self-check-in }\end{array}$ & $\begin{array}{l}\text { Some customers stated the customer } \\
\text { involvement during the ticketing process as } \\
\text { well as during e-ticketing and the self-check-in } \\
\text { as an important attribute. }\end{array}$ \\
\hline Simple Handling & $\begin{array}{l}\text { Booking processes } \\
\text { instructions/ } \\
\text { information }\end{array}$ & $\begin{array}{l}\text { Customers want the booking processes and all } \\
\text { associated handling process including } \\
\text { instructions and information given at the } \\
\text { airport to be clear and succinct. }\end{array}$ \\
\hline $\begin{array}{l}\text { Costs For Getting } \\
\text { At Airport }\end{array}$ & $\begin{array}{l}\text { Time costs } \\
\text { financial costs }\end{array}$ & $\begin{array}{l}\text { Costs associated with getting to and from the } \\
\text { airport were mentioned with respect to both } \\
\text { time and money, factors that are dependent } \\
\text { on the location and accessibility of the airport. }\end{array}$ \\
\hline Business Offers & $\begin{array}{l}\text { Lounge access } \\
\text { priority check-in } \\
\text { priority luggage }\end{array}$ & $\begin{array}{l}\text { This attribute was mentioned in relation with } \\
\text { the lounge access, priority check-in and } \\
\text { priority luggage. }\end{array}$ \\
\hline
\end{tabular}




\section{HIERARCHICAL VALUE MAPS}

The possible value associations between the investigated attribute and attribute levels are identified by creating hierarchical value maps. In a first step, functional and psychological consequences were detected based on the explicit answers given during the laddering interviews. Potential implicit instrumental and terminal values were then derived from the identified consequences.

Each individual has underlying values with respect to preferred modes of behaviour (instrumental values) and preferred modes of being (terminal values). Usually, customers associate consequences, which may be either benefits or risks, with the consumption of certain products or services, which may then lead to personal values. As a result, individuals prefer to consume products that embody their personal values and might serve as instruments to achieve their final preferred modes of being. Figures 2 and 3 show instrumental value maps for service quality and cost element. Service quality is the attribute most frequently stated by the respondents, though it was in context with various attribute levels and various consequences. For example, excellent service leads to the functional consequence of a convenient flight and the psychological consequence of feeling appreciated and having a positive flight experience. From this, it was concluded that these consequences are linked to the instrumental values of act respectfully, politely and, mannerly, which in turn leads to the terminal values of contentment and happiness. By referring to the professionalism of the staff, it is concluded that the interviewees link this with a convenient, comfortable flight and a feeling of safety, which in turn leads to the terminal value of having a secure and safe life.

Overall, service quality is highly valued by passengers as it leads to various pursued values such as friendship, caring for loved ones, social recognition, contentment, pleasure and security. 
Figure 2: Service Quality Map

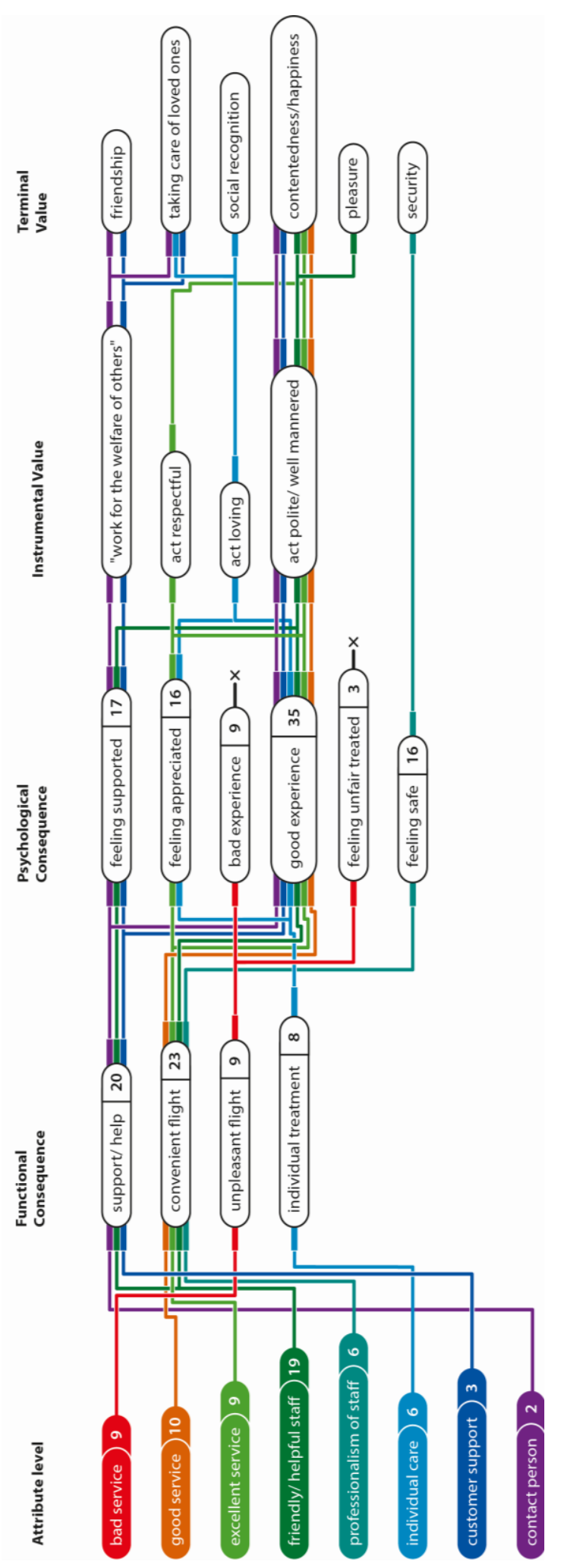

Figure 3: Cost Element Map

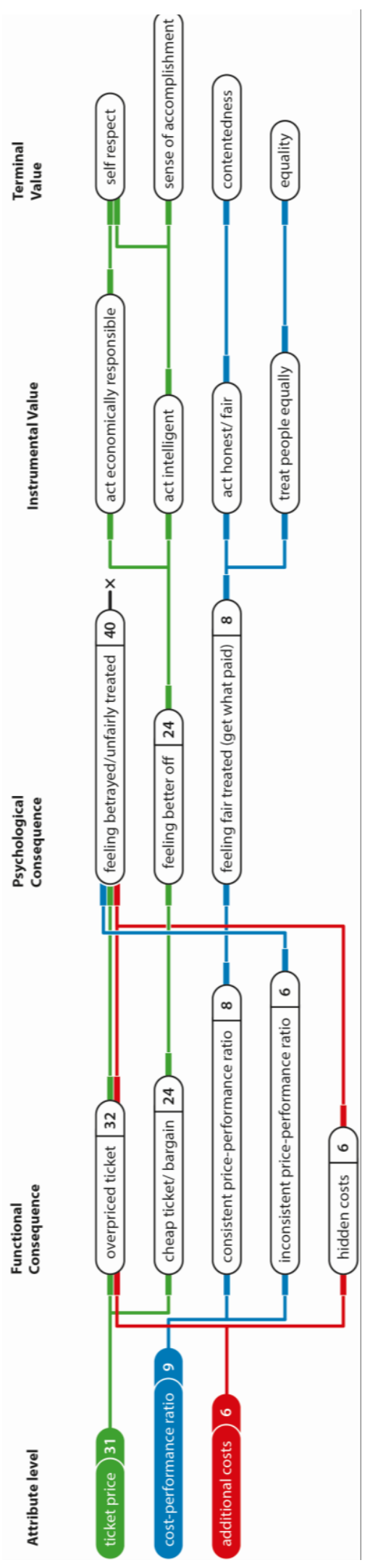


The cost element, which is illustrated below, involves three attribute levels that lead to different functional consequences, such as an overpriced or cheap ticket, a consistent or inconsistent costperformance ratio and hidden costs. Such functional consequences, in turn, result in psychological consequences such as feeling betrayed or victimised or feeling well compensated. Finally, it is probable that consumers want to attain the terminal values of self-respect, a sense of accomplishment, contentment and equality.

\subsection{Expectations of Airline Categories}

One part of the interview was designed to identify customer expectations and perceptions of different airline categories. The categories were divided into low-cost carriers, major airlines and premium airlines. LCC's include airlines such as easyJet, Ryanair and Southwest Airlines. Major airlines include normal size carriers such as Swiss, Lufthansa, Air France and British Airways whereas premium airlines are represented by carriers such as Singapore Airlines and Emirates.

Frequently mentioned attributes relating to expectations of low-cost carriers are cheap tickets, easy and accessible transportation from one place to another, additional and hidden costs, less or no free on-board catering, fewer included services (reduced to the minimum) and reduced or even poor service quality. There are also some repeatedly mentioned characteristics, some positive and some negative. These include, on the positive side, sufficient safety and security standards, friendly and helpful staff, fast booking process, efficient general handling processes, a high degree of capacity utilisation, individual package creation and different marketing activities in comparison to other airlines. Negative characteristics associated with LCCs are low level of comfort, poor customer support, use of old aircraft and outdated equipment, less professional staff, unexpected flight cancellations, delays and poorly located airports.

In connection with major airlines, interviewees consistently mentioned the high service quality. They also frequently mentioned the free on-board catering and the complementary services. Repeatedly mentioned attributes included high level of comfort, friendly and helpful staff, good safety and security standards, quality at all levels, good customer support, interesting entertainment programs, modern fleet and contemporary interior equipment, reasonable priceperformance ratios, punctuality, efficient processes, professional staff, greater number of destinations, no luggage problems, good communication with consumers and lounge access. The only negative concern was related to high costs for tickets.

Finally, in a third step, the interviewees were asked to identify further expectations based on a comparison between major airlines and premium airlines. The majority of the respondents cited the exclusive, high level service performance offered by premium airlines. They also repeatedly 
mentioned attributes such as high-tech entertainment programs, modern equipment and design, superior quality at all levels, friendly and attentive staff, professional and multilingual staff, individual customer care, exceptional comfort level, excellent on-board catering, state-of-the-art technology, highly positive flight experience, modern fleet, nice lounges, punctuality, reliability and new and innovative service offerings.

\subsection{Possible Impacts on Future Image Perception}

There are possible impacts of introducing an ancillary revenue pricing system on the future image perception of full service carriers. In a first step, respondents were asked what personal advantages and disadvantages they would expect from such a system. They were asked to consider the potential impacts and changes on the overall image perception of airlines.

Results from the interviews indicate that most respondents have mixed feelings regarding an ancillary pricing system. On the one hand, many emphasised the advantage of customisation and individual ticket creation, which is perceived as an extended benefit that further strengthens the loyalty towards the Swiss brand. They appreciate the opportunity to be involved in the ticket creation process and to have a flight that meets their specific requirements. In the opinion of these respondents, such a customisation option would further improve the price performance relationship and would accordingly result in flexibility gains as it allows for the airline to offer more precise service options.

In general, there was no apparent tendency with respect to changes in image perceptions among the different age groups. Surprisingly, many participants in the age groups 30 to 50 and 51 or above demonstrated positive, or at least uncertain, attitudes towards such a pricing approach. Many of these participants believe that this system reflects a progressive idea that may be quite conceivable in the future as it is a customer-oriented approach.

On the other hand, several interviewees raised concerns about implementing this system. Most notably, people who did not travel regularly or who only infrequently booked their tickets online were concerned that the booking process might become too complex and too time-intensive with this approach. Furthermore, inexperienced users felt uncertain or overwhelmed as they were worried about forgetting certain add-ons or neglecting other important issues. Thus, these participants indicated that they prefer the status quo.

Another major issue, which is perceived as critical by the interviewees, is the deformation or distortion of the competitive behaviour. Because ancillary revenues were originally perceived as an LCC pricing strategy, this approach bears the risk of altering the image of the airline. Several respondents stated that the airline might undergo a shift in the low-cost airline category and be in 
direct price wars with them. Although the implied consequences are not evident, passengers are confident that the current quality and service standards of the airlines will be maintained. The consequence might be that Swiss customers act on this assumption and thus perceive a decline in quality and service when, in fact, there has been the standards have remained intact.

However, this topic is highly controversial and the majority of passengers advanced the opinion that the image highly depends on the way the change is communicated. When customers believe that they are paying additional fees for services that had typically been included in their package, they experience a negative psychological consequence as they believe they are being prevented from satisfying their personal values.

\section{$5 \quad$ SUMMARY AND CONCLUSIONS}

The knowledge about crucial attributes that are influencing consumers while booking, experiencing and post-evaluating the purchase of a flight ticket, provide a useful background to better understand customer behaviour in the flight ticket purchase process. By interpreting underlying preferred modes of behaviour (instrumental values) as well as end states of being (terminal values), it was found that values such as living a secure and safe life and caring for others are the values most pursued by passengers. By understanding which attributes are of high customer value and by identifying their possible sources, airlines can actively improve their service with respect to these specific attributes.

Further, the analysis of expectations and perceptions of different airline categories can be effectively used for airline positioning. When implementing a new pricing strategy, such as the ancillary revenue approach, airlines should consciously avoid shifting towards the expectations of low-cost airlines.

Based on the literature and on empirical findings, the suitable response would be that the success of this pricing system is dependent on its implementation and on the means of communicating information about the system.

A possible option would allow passengers to choose a flight package that involves different services and allows the passenger to deselect ancillary services that they do not need. By providing such an offer, passengers who prefer to purchase a complete package because they do not want to spend time on or are overextended by the booking process can buy their flight ticket according to the traditional method. In contrast, passengers who want to customise their packages can select flight attributes that allow them to access underlying values. A further positive consequence of this system is that at the beginning of the booking process an overall airfare is indicated to the 
customers and they can then take advantage of price discounts by deselecting services. Thus, they do not feel as if they are paying extra for every service, but rather, they are able to find a better price if they take their time and adapt the ticket to their individual needs.

It is concluded that an ancillary revenue system bears risks as well as opportunities. The importance lies in the fact that full service airlines understand how they want to differentiate themselves from low-cost carriers and that they clearly distinguish themselves by establishing a unique selling proposition that does not only focus on the financial aspects but also emphasises additional benefits. There are limitations to this study that lead to further research in the field of ancillary revenue pricing. First, the learning of passengers (learning curve) could be taken into account especially when evaluating the buying behaviour during the buying process. Passengers learn and are assumed to adjust to new forms of booking or selection services. Second, information technology could have an impact on pricing. It could be assumed that personalised pricing is fact, which would then have an impact on the perception of prices and on subsequent behaviour. 


\section{REFERENCES}

- Air Canada (2013): Tarifbestandteile. Accessed on June 14, 2013 at http://www.aircanada.com/de/shared/de/aco/flights/pop_faretypes_transborder.html

- Alderighi, M., Cento, A., Nijkamp, P. \& Rietveld, P. (2012): Competition in the European aviation market: the entry of low-cost airlines. Journal of Transport Geography, 24, pp. 223233

- Basso, L.J \& Zhang, A. (2008): On the relationship between airport pricing models. Transportation Research Part B, 42, pp. 725-735

- $\quad$ Batra, S.K. \& Kazmi, S.H.H. (2009): Consumer Behaviour - Text and Cases. New Dehli: Excel Books

- Chi, J. \& Koo, W.W. (2009): Carriers' pricing behaviors in the United States airline industry.Transportation Research Part E, 45, pp. 710-724

- Granados, N., Kauffman, R.J., Lai, H. \& Lin, H. (2012): À la carte pricing and price elasticityof demand in air travel. Decision Support Systems, 53, pp. 381-394

- Groote, P.D. (2005): The Success Story of European Low-Cost Carriers in a Changing Airworld. Research Bulletin. Proceedings of the BIVEC-GIBET Transport Research Day 2005 Diepenbeek, pp. $87-110$

- Gunther, D., Ratliff, R. \& Sylla, A. (2012): Airline Distribution. In C. Barnhart \& B. Smith (Eds.). Airline Quantitative Problem Solving Methods in the Airline Industry. A Modeling Methodology Handbook (pp. 163-237). New York: Springer Science \& Business Media

- Gutman, J. (1981): A Means-End Model For Facilitating Analyses of Product Markets Based on Consumer Judgement. Advances in Consumer Research, 8. pp. 116-121

- Hernandez, M.A., Sengupta, A. \& Wiggins, S.N. (2012): Examining the effect of low-cost carriers on nonlinear pricing strategies of legacy carriers. In J. Peoples (Ed.). Pricing Behavior and Non-Price Characteristics in the Airline Industry (pp. 11-45). Bingley: Emerald Group Publishing Limited.

- Kuss, A. \& Tomczak, T. (2007a): Individuelle Ausgangsbedingungen des Kaufverhaltens. In

- $\quad$ F.X. Bea \& M. Schweizer (Eds.). Käuferverhalten (pp. 49-73). Stuttgart: Lucius \& Lucius

- Luo, L. \& Peng, J. (2007): Dynamic Pricing Model for Airline Revenue Management under Competition. Systems Engineering - Theory \& Practice, 27 (11), pp. 15-25

- Malighetti, P., Paleari, S. \& Redondi, R. (2009): Pricing strategies of low-cost airlines: TheRyanair case study. Journal of Air Transport Management, 15, pp. 195-203 
- McGraw-Hill (2013): Customers' Product Knowledge and Involvement. Accessed on April 24, 2013 at http://answers.mheducation.com/marketing/consumer-behavior/customers-productknowledge-and-involvement

- Peoples, J. (2012): Pricing behavior and non-price characteristics of the airline industry: introduction and overview. In J. Peoples (Ed.). Pricing Behavior and Non-Price Characteristics in the Airline Industry (pp. 1-9). Bingley: Emerald Group Publishing Limited

- Samoa Air (2013): How does 'Pay by weight' work? Accessed on July 4, 2013 at http://www.samoaair.ws/index.php/booking-2/pay-by-weight

- Schiffman, L.G. \& Kanuk, L.L. (2007): Consumer Behavior. New Jersey: Pearson Education

- Solomon, M.R. (2011): Consumer Behavior - Buying, Having and Being. New Jersey: Pearson Education

- Tuttle, B. (2012): Coming Soon? Airline tickets that cost extra after you purchase them. Time Inc. Accessed on July 3, 2013 at http://business.time.com/2012/09/28/coming-soon-airlinetickets-that-cost-extra-after-you-purchase-them/

- Tuttle, B. (2013a): Air Travel by the Pound and Other Odd Airline Pricing Schemes. Accessed on May 23, 2013 at http://business.time.com/2013/04/08/air-travel-by-the-pound-and-otherodd-airline-pricing-schemes/

- Tuttle, B. (2013b): Flight prices to get personal? Airfares could vary depending on who is traveling. Time Inc. Accessed on July 3, 2013 at http://business.time.com/2013/03/05/flightprices-to-get-personal-airfares-could-vary-depending-on-who-is-traveling/

- UXmatters (2013): Laddering: A Research Interview Technique for Uncovering Core Values. Accessed on April 24, 2013 at http://www.uxmatters.com/mt/archives/2009/07/laddering-aresearch-interview-technique-for-uncovering-core-values.php

- Wittmer, A., Rowley, E. (2014): Customer value of purchasable supplementary services - The case of a full network carriers' economy class. In: Journal of Air Transport Management, Vol. 34, pp. 17-23, 2014.

- Wittmer, A., Riegler, B. (2014): Purchasing a general ticket for public transport - a means end approach. In: Travel behavior and Society, Vol. 1, No. 3, 2014, pp $106-112$.

- Wittmer, A., Boksberger, Ph., Gerber, A. (2012): The future of ancillary service fees in air travel - an exploratory investigation of budget air travelers. In: International Journal of Aviation Management, Vol.1, No. 4, 2012, pp 231-241.

- Wittmer, A., Riegler, B. (2013): Customer behavior of rail customers season ticket buying process: The case of Swiss Railways. 13th WCTR Conference, 15-18 July 2013, Rio, Brazil.

- Wong, Kaufui V. / Hernandez, Aldo (2012), 'A Review of Additive Manufacturing', Hindawi Publishing Corporation, http://www.hindawi.com 